\title{
Accelerated aging of forensically relevant biological materials on swabs
}

\author{
Abigail S Bathrick*,1 (iD) \& Jon M Davoren ${ }^{1}$ \\ ${ }^{1}$ Bode Technology, 10430 Furnace Road, Suite 107, Lorton, VA 22079, USA; *Author for correspondence: abby.bathrick@bodetech.com
}

BioTechniques 70: 233-238 (April 2021) 10.2144/btn-2020-0170

First draft submitted: 15 December 2020; Accepted for publication: 10 February 2021; Published online: 2 March 2021

\section{ABSTRACT}

The preservation of DNA in biological samples is important for forensic testing, as samples can be tested years or even decades after collection. Generally, the DNA within biological evidence is stable over shorter time frames but can degrade over extended periods. In this work, we evaluated accelerated aging as a method to reduce the duration of studies examining the stability of DNA in forensic evidence-type samples. Evaluation of the DNA extracted from cells stored at 37 and $50^{\circ} \mathrm{C}$ for 194 or 79 days, respectively, showed similar quality metrics to cells stored at $25^{\circ} \mathrm{C}$ for 548 days.

\section{METHOD SUMMARY}

Human blood, saliva, semen and vaginal cells were spotted onto cotton swabs and stored at 25,37 and $50^{\circ} \mathrm{C}$ for 548,194 and 79 days, respectively. DNA was extracted from the samples before storage began and at one-third total storage time (TST), two-thirds TST and TST. Following extraction, DNA was assessed by both real-time PCR of 80- and 214-bp amplicons and PCR of short tandem repeats ranging from approximately 100 to 400 bp.

\section{KEYWORDS:}

degradation $\bullet$ DNA • forensic science $\bullet$ quantification $\bullet$ short tandem repeats • stability

The stability, degradation and preservation of DNA associated with biological reference and evidence items have been topics of interest in the forensic community and other fields for decades [1-5]. Although DNA is fairly stable due to its structure, it is susceptible to degradation by oxidation and hydrolysis over time [6]. The breakdown of DNA can be problematic when biological evidence samples (e.g., sexual assault kits) undergo long-term storage before processing [7,8]. Long-term controlled studies can aid in evaluating and improving methods for the collection, storage and preservation of biological evidence for DNA analysis. Such studies, however, can be difficult to execute due to the amount of time required for sample storage. Results from long-term time studies processed in real time may be of diminished relevance due to obsolescence of the technology or methods used to process the early time points and the emergence of improved or new testing methodologies.

Accelerated aging (AA) of samples may be used to address these challenges. AA is a technique used to simulate aging of medical devices when real-time aging is not feasible. The simplified protocol for $A A$, or the 10-degree rule, states that a temperature increase of $10^{\circ} \mathrm{C}$ roughly doubles the rate of aging $\left(\mathrm{Q}_{10}=2\right)$ :

$$
\mathrm{TIME}_{\mathrm{T} 1}=\mathrm{TIME}_{\mathrm{RT}} / \mathrm{Q}_{10}^{\left(\mathrm{T}_{1}-\mathrm{T}_{\mathrm{RT}}\right) / 10}
$$

where $\mathrm{T} 1=$ oven aging temperature, $\mathrm{T}_{\mathrm{RT}}=$ room temperature $\left(22^{\circ} \mathrm{C}\right)$ and $\mathrm{Q}_{10}=$ reaction-rate coefficient $[9,10]$. Although this technique has previously been used to simulate the aging of DNA extracts [11,12], its efficacy for replicating potential degradation has not been examined on forensically relevant biological materials to determine whether AA adequately simulates degradation relative to real-time aging. In this study, blood, saliva, semen and vaginal cell samples were aged in real time and with $\mathrm{AA}$ at 37 and $50^{\circ} \mathrm{C}$ to determine the viability of this technique for examining the stability of DNA in forensically relevant biological materials and evidence.

Human blood and semen were purchased from Biological Specialty Corporation (PA, USA). Saliva and vaginal swabs were collected from internal donors under institutional review board guidelines with informed consent. No preservatives were added to the biological materials during or after collection. Following collection, vaginal cells were eluted from the swabs into $1 \times$ phosphate-buffered saline. The DNA concentration of each biological material was estimated by extracting $20 \mu \mathrm{l}$ blood, $50 \mu \mathrm{l}$ saliva, $20 \mu \mathrm{l}$ semen and $50 \mu \mathrm{l}$ vaginal cell suspension in triplicate on the Qiagen ${ }^{\circledR}$ QIAsymphony robot with the QIAsymphony ${ }^{\circledR}$ DNA Investigator ${ }^{\circledR}$ Kit (Qiagen, MD, USA) and quantifying the extracts using the Quantifiler ${ }^{\circledR}$ Trio DNA Quantification Kit (Thermo Fisher Scientific, MA, USA). For each biological material, the volume to be applied to the swabs was selected so that the total DNA yield of the extracts would exceed trace quantities ( $>0.5 \mathrm{ng}$ ) when considering potential DNA loss during extraction (Table 1). Excluding the vaginal cell suspension, biological materials 


\begin{tabular}{|c|c|c|c|c|c|}
\hline Biological material & Amount extracted $(\mu \mathrm{l})$ & Elution volume $(\mu \mathrm{l})$ & $\begin{array}{l}\text { DNA extract } \\
\text { DNA conc. }(\mathrm{ng} / \mu \mathrm{l})\end{array}$ & $\begin{array}{l}\text { Biological material DNA } \\
\text { conc. }(\mathrm{ng} / \mu \mathrm{l})\end{array}$ & Volume applied $(\mu \mathrm{l})$ \\
\hline Blood & 20 & 50 & 4.4 & 11.0 & 5 \\
\hline Saliva & 50 & 50 & 5.9 & 5.9 & 5 \\
\hline Semen & 20 & 50 & 49.3 & 123.3 & 5 \\
\hline Vaginal cell suspension & 50 & 50 & 4.5 & $4.5^{\dagger}$ & 10 \\
\hline
\end{tabular}

$\dagger$ Vaginal cell suspension was diluted to $1 \mathrm{ng} / \mu \mathrm{l}$ in $1 \times$ phosphate-buffered saline prior to application to swabs.

Table 2. Storage temperature, time points and accelerated aging storage time equivalents.

\begin{tabular}{|c|c|c|}
\hline Storage temperature $\left({ }^{\circ} \mathrm{C}\right)$ & Time stored (days) & Storage time equivalent (days) \\
\hline \multirow[t]{4}{*}{25} & 0 & - \\
\hline & 183 & - \\
\hline & 365 & - \\
\hline & 548 & - \\
\hline \multirow[t]{3}{*}{37} & 65 & 183 \\
\hline & 129 & 365 \\
\hline & 194 & 548 \\
\hline \multirow[t]{3}{*}{50} & 26 & 183 \\
\hline & 52 & 365 \\
\hline & 79 & 548 \\
\hline
\end{tabular}

were not diluted to preserve their integrity. Volumes $>1 \mu \mathrm{l}$ were selected to minimize pipetting error. Blood $(5 \mu \mathrm{l})$, saliva $(5 \mu \mathrm{l})$, semen $(5 \mu \mathrm{l})$ and vaginal cell suspension $(10 \mu \mathrm{l})$ were applied to the tips of sterile cotton swabs (Puritan, ME, USA). Following application of the biological samples, all the swabs were dried at room temperature overnight, placed in cardboard swab boxes and stored at 25,37 or $50^{\circ} \mathrm{C}$ with ambient relative humidity. Real-time aging and AA studies were conducted simultaneously, and samples were tested at the time points specified in Table 2. Samples were prepared in triplicate for each biological sample type, storage temperature and time point $(n=120)$.

DNA extraction was performed on the Qiagen QIAsymphony robot with the QIAsymphony DNA Investigator Kit. After extraction, $2 \mu \mathrm{I}$ of each sample was quantified using the Quantifiler Trio DNA Quantification Kit with $11 \mu$ l reaction volumes on the Applied Biosystems ${ }^{\top M}$ 7500 Real-Time PCR System (Thermo Fisher Scientific). Samples that contained $<0.067 \mathrm{ng} / \mu$ of DNA were concentrated with Microcon DNA Fast Flow columns (MilliporeSigma, MA, USA). A template DNA quantity of $0.5 \mathrm{ng}$ was targeted for amplification. Amplification was performed with the GlobalFiler ${ }^{T M}$ PCR Amplification Kit (Thermo Fisher Scientific) using $12.5 \mu l$ reaction volumes and 28 amplification cycles. Capillary electrophoresis was performed on the 3500xL Genetic Analyzer for Human Identification (Thermo Fisher Scientific), and data were analyzed with Applied Biosystems' GeneMapper ID-X ${ }^{\circledR}$ V. 1.5 (Thermo Fisher Scientific) using an analytical threshold of 125 relative fluorescence units and a stochastic threshold of 600 relative fluorescence units. JMP ${ }^{\circledR}$ Statistical Discovery ${ }^{T M}$ Software v. 12.2 (SAS ${ }^{\circledR}$ Institute Inc., NC, USA) was used to perform all statistical analyses. Dunnett's test was used to perform comparisons across time points using the 0-day time point as the control. Tukey's honest significant difference tests were employed to perform comparisons between the $25^{\circ} \mathrm{C}$ real-time, $37^{\circ} \mathrm{C}$ AA and $50^{\circ} \mathrm{C}$ AA samples.

Mean DNA yields obtained from the samples are shown in Table 3. The blood and semen had the highest DNA yields, whereas the saliva and vaginal cell samples had much lower starting DNA levels. Using Dunnett's test, no statistically significant reductions in DNA yield were observed in the blood, saliva and semen samples when stored at any temperature for any length of time when compared with the control $(\alpha=0.01)$. Apparent increases in DNA concentration after storage $\geq 183$ days were not statistically significant and can likely be attributed to variability within the sample sets caused by uneven distribution of cells in the biological materials. The vaginal cell samples demonstrated statistically significant decreases in DNA yield when stored for the equivalent of 365 days at 25,37 and $50^{\circ} \mathrm{C}$ and 548 days at 25 and $50^{\circ} \mathrm{C}(\mathrm{p}<0.001,0.007,0.001,<0.001$ and $<0.001$, respectively).

DNA degradation was assessed by examining two metrics: mean Quantifiler Trio degradation index (DI) values (Figure 1A) and mean interlocus balance (Figure 1B). Quantifiler Trio utilizes a small human target ( $80 \mathrm{bp}$ ) and large human target (214 bp) to provide quality information on the samples being analyzed. A DI value was generated for each sample based on the ratio of the small and large amplicons. Degradation detected via $\mathrm{DI}$ ranged from none $(\mathrm{DI} \leq 1)$ to slight $(1<\mathrm{DI} \leq 10)$ in the blood samples and slight to moderate $(1 \leq \mathrm{DI} \leq 10)$ in the saliva samples. No degradation (DI $<1)$ was indicated in the semen and vaginal cell samples. Severe degradation (DI $>10)$ was not observed for any sample type. Interlocus balance was determined by comparing the signal strength from the TPOX ( $\sim 400$ bp) and D3S1358 ( $100 \mathrm{bp}$ ) loci. With this metric, there was also little degradation observed in the blood and semen samples, whereas the saliva 
Table 3. Mean DNA yields and standard deviations for each biological material, storage temperature and storage time equivalent.

\begin{tabular}{|c|c|c|c|c|c|}
\hline \multirow[t]{2}{*}{ Time equivalent (days) } & \multirow[t]{2}{*}{ Storage temperature $\left({ }^{\circ} \mathrm{C}\right)$} & \multicolumn{4}{|c|}{ Mean DNA yield (ng) } \\
\hline & & Blood & Saliva & Semen & Vaginal cells \\
\hline 0 & 25 & $57.0 \pm 23.3$ & $6.5 \pm 1.9$ & $2983.3 \pm 2356.0$ & $6.3 \pm 1.5$ \\
\hline \multirow[t]{3}{*}{183} & 25 & $83.3 \pm 56.2$ & $5.9 \pm 0.6$ & $6380.0 \pm 1200.8$ & $4.3 \pm 0.6$ \\
\hline & 37 & $52.2 \pm 7.2$ & $7.0 \pm 2.0$ & $2273.3 \pm 805.1$ & $1.4 \pm 0.4$ \\
\hline & 50 & $51.3 \pm 14.3$ & $3.4 \pm 0.7$ & $2950.0 \pm 726.4$ & $1.0 \pm 0.4$ \\
\hline \multirow[t]{3}{*}{365} & 25 & $53.0 \pm 17.4$ & $3.3 \pm 1.0$ & $2527.7 \pm 1673.6$ & $3.5 \pm 2.1$ \\
\hline & 37 & $77.8 \pm 20.5$ & $2.8 \pm 0.7$ & $3670.0 \pm 1653.1$ & $1.7 \pm 0.4$ \\
\hline & 50 & $56.8 \pm 29.2$ & $3.6 \pm 1.2$ & $2856.7 \pm 1287.4$ & $2.5 \pm 0.6$ \\
\hline \multirow[t]{3}{*}{548} & 25 & $55.7 \pm 13.8$ & $4.4 \pm 0.8$ & $3696.7 \pm 1140.5$ & $3.8 \pm 0.4$ \\
\hline & 37 & $44.0 \pm 13.0$ & $4.2 \pm 0.6$ & $4606.7 \pm 1581.5$ & $2.3 \pm 0.5$ \\
\hline & 50 & $45.3 \pm 5.9$ & $6.0 \pm 0.8$ & $2420.0 \pm 283.5$ & $1.6 \pm 0.4$ \\
\hline
\end{tabular}

(A)

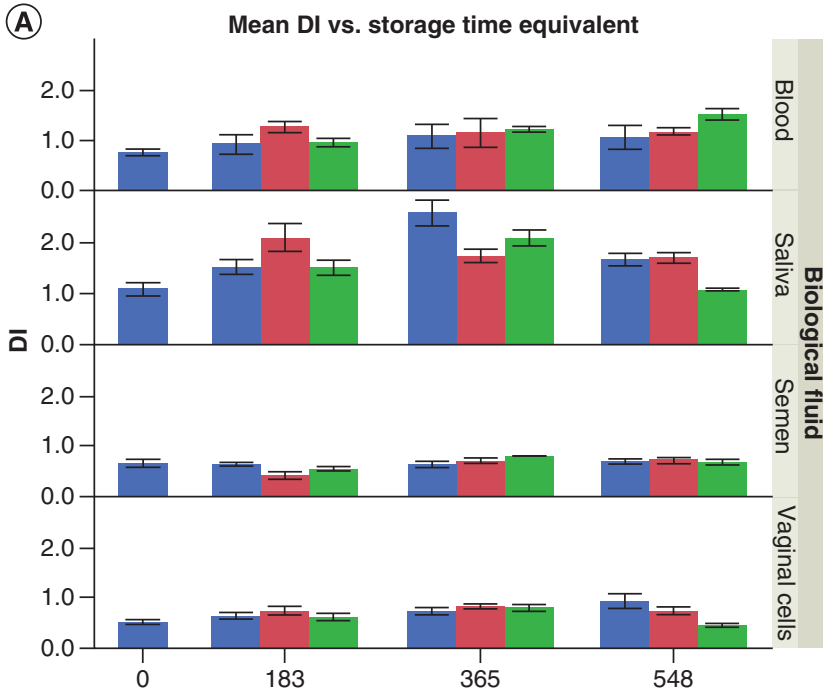

Storage time equivalent (days)
(B) Mean inter-locus balance vs. storage time equivalent
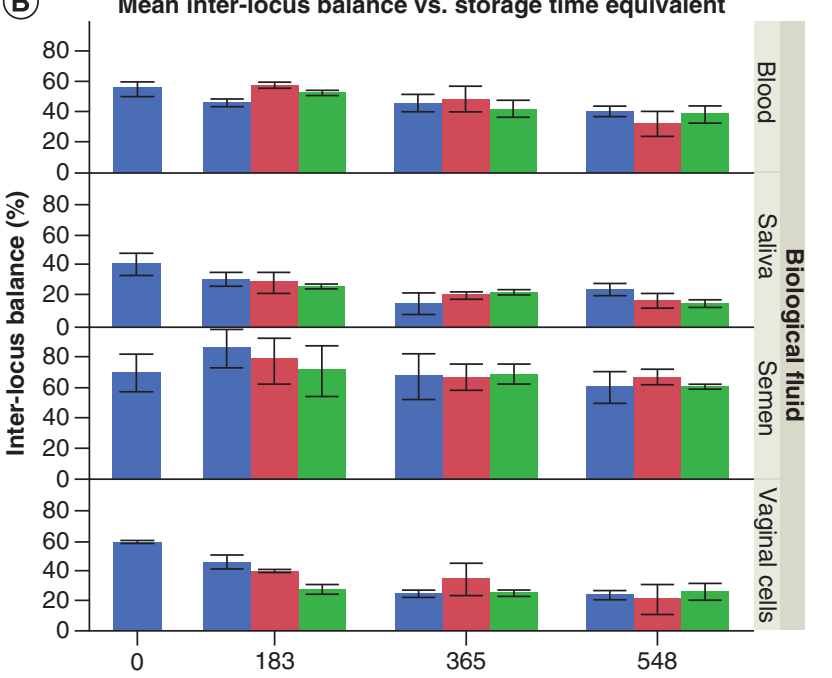

Storage time equivalent (days)

Figure 1. Mean (A) degradation index values and (B) interlocus balance for each biological material, storage temperature and storage time equivalent. DI: Degradation index.

and vaginal cells showed interlocus balances of $<30 \%$ at the last time point, which was indicative of DNA degradation. Pairwise Tukey's honest significant difference comparisons of the DI values and interlocus balances revealed several statistically significant differences between the storage temperatures at each storage time equivalent $(\alpha=0.01)$ (Table 4$)$.

DNA quality was also evaluated by assigning a quality score to each profile based on Hedman et al.'s forensic DNA profile index (FI) [13]. This index establishes a single quantitative quality score for each DNA profile by considering three factors: overall peak height, intralocus peak height balance and peak height balance across all loci. A score of 10 represented the highest quality profiles, whereas a score of 0.05 represented the lowest quality or no profiles. To determine the practical implications of these differences on short tandem repeat (STR) profile quality, the corresponding mean FI values were examined (Figure 2) and compared for statistically significant differences (Table 4). Mean FI values indicated that the blood, semen and vaginal cell samples generated high quality STR profiles (FI $\geq 6$ ). Across all storage temperatures and storage time equivalents, saliva was found to be the least stable biological material and generated moderate-quality STR profiles $(4 \leq \mathrm{FI}<6)$ in which all expected alleles were present and above the analytical and stochastic thresholds, although the peak height values and balance across and within the loci were lower than those observed in the profiles 
Benchmark

\begin{tabular}{|c|c|c|c|c|c|c|c|c|c|c|c|c|c|c|}
\hline \multirow{2}{*}{$\begin{array}{l}\text { Time } \\
\text { equiva- } \\
\text { lent } \\
\text { (days) }\end{array}$} & \multicolumn{2}{|c|}{$\begin{array}{l}\text { Temperatures } \\
\text { compared }\left({ }^{\circ} \mathrm{C}\right)\end{array}$} & \multicolumn{3}{|c|}{ Blood } & \multicolumn{3}{|c|}{ Saliva } & \multicolumn{3}{|c|}{ Semen } & \multicolumn{3}{|c|}{ Vaginal cells } \\
\hline & & & DI & Balance & FI & DI & Balance & FI & DI & Balance & FI & DI & Balance & FI \\
\hline \multirow[t]{3}{*}{183} & 25 & 37 & 0.064 & $0.001^{\ddagger}$ & 0.142 & 0.027 & 0.909 & 0.405 & $0.005^{\dagger}$ & 0.783 & 0.192 & 0.337 & 0.127 & 0.271 \\
\hline & 25 & 50 & 0.961 & 0.022 & 0.395 & 0.997 & 0.509 & 0.337 & 0.147 & 0.457 & 0.192 & 0.885 & $0.001^{\dagger}$ & 0.460 \\
\hline & 37 & 50 & 0.089 & 0.056 & 0.699 & 0.030 & 0.742 & 0.986 & 0.061 & 0.827 & 0.029 & 0.188 & $0.006^{\dagger}$ & 0.893 \\
\hline \multirow[t]{3}{*}{365} & 25 & 37 & 0.917 & 0.878 & 0.012 & $0.004^{\dagger}$ & 0.362 & 0.413 & 0.082 & 0.997 & $0.002^{\ddagger}$ & 0.132 & 0.245 & $0.003^{\ddagger}$ \\
\hline & 25 & 50 & 0.749 & 0.786 & 0.021 & 0.045 & 0.183 & 0.999 & $0.003^{\ddagger}$ & 0.988 & 0.823 & 0.504 & 0.998 & 0.471 \\
\hline & 37 & 50 & 0.938 & 0.513 & 0.865 & 0.133 & 0.847 & 0.394 & 0.056 & 0.972 & $0.002^{\dagger}$ & 0.540 & 0.265 & $0.009^{\dagger}$ \\
\hline \multirow[t]{3}{*}{548} & 25 & 37 & 0.659 & 0.309 & 0.063 & 0.934 & 0.140 & 0.077 & 0.847 & 0.414 & 0.490 & 0.121 & 0.905 & 0.275 \\
\hline & 25 & 50 & 0.029 & 0.915 & 0.043 & $0.001^{\dagger}$ & 0.064 & 0.013 & 0.986 & 0.981 & 0.470 & $0.002^{\dagger}$ & 0.905 & 0.297 \\
\hline & 37 & 50 & 0.087 & 0.488 & 0.953 & $<0.001^{\dagger}$ & 0.818 & 0.336 & 0.847 & 0.506 & 0.107 & 0.018 & 0.685 & 0.998 \\
\hline
\end{tabular}

$\dagger$ The temperature listed first produced significantly higher values; $p<0.01$.

¥The temperature listed second produced significantly higher values; $p<0.01$.

DI: Degradation index; Fl: Forensic DNA profile index.

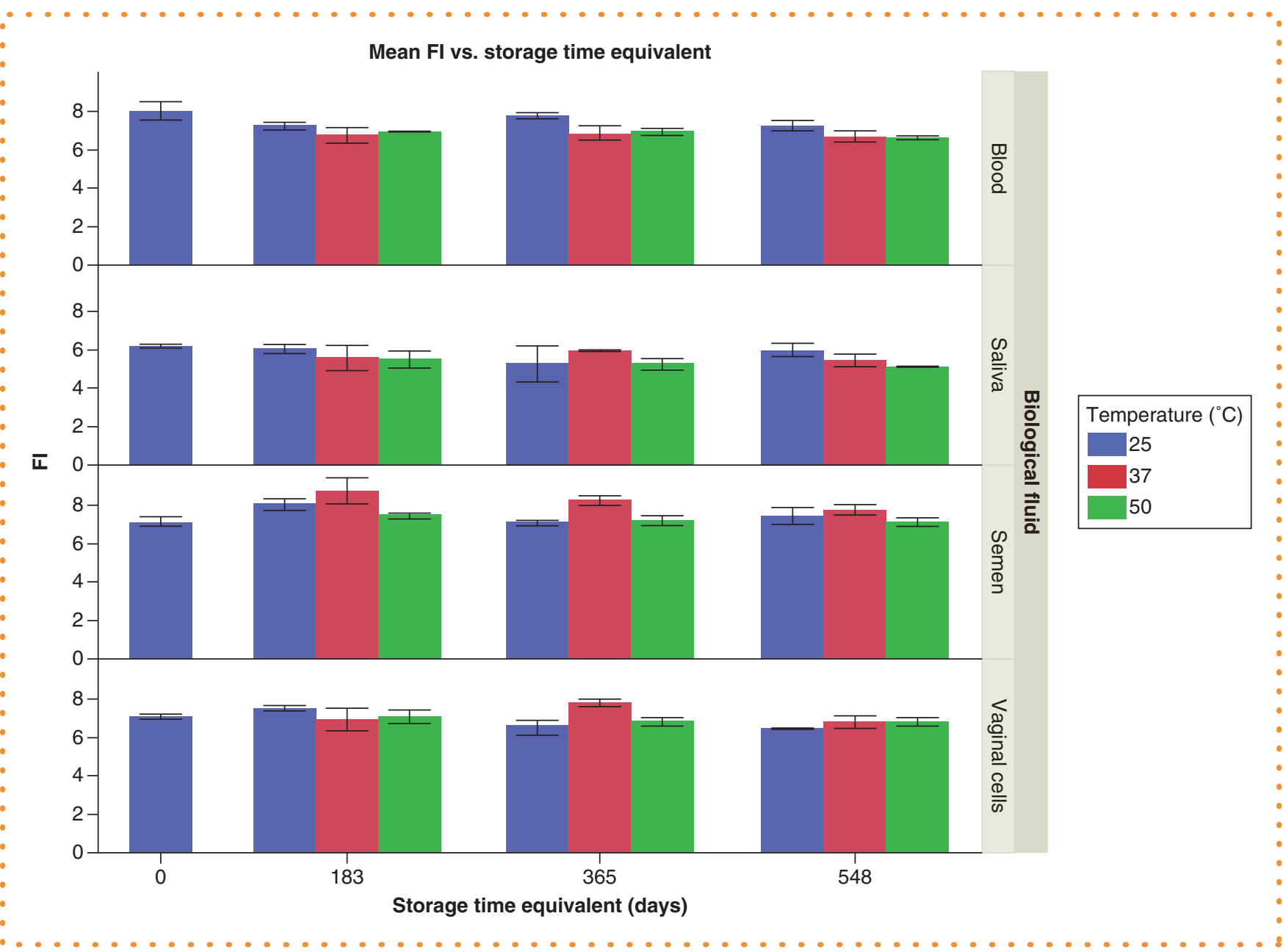

Figure 2. Mean forensic DNA profile index for each biological material, storage temperature and storage time equivalent.

FI: Forensic DNA profile index. 
generated by the other sample types. Poor quality STR profiles with allelic dropout and severe imbalance were not observed for any sample type.

Variations in DI, interlocus balance and FI were only considered impactful when statistically significant differences were observed in all three metrics, which indicated that DI and interlocus balance changes corresponded to a measurable difference in profile quality and that $\mathrm{FI}$ changes could be attributed to DNA degradation. No statistically significant differences in every metric were observed for any comparison. These data support the use of $A A$ at 37 and $50^{\circ} \mathrm{C}$ for an equivalent of up to 548 days. While the data indicate that AA may be viable for longer time periods, additional studies are required to assess the efficacy of this technique for replicating potential degradation in biological materials beyond 548 days. Furthermore, although no statistically significant differences in DI, intralocus balance and FI were observed in pairwise comparisons of 37 and $50^{\circ} \mathrm{C}$, this should be confirmed against real-time data for storage time equivalents greater than 548 days.

In summary, AA at 37 and $50^{\circ} \mathrm{C}$ for an equivalent of up to 548 days is a viable alternative for real-time aging of blood, saliva, semen and vaginal cell samples in long-term time studies. AA data will be particularly beneficial for pilot studies and initial evaluations of methods for collection, storage and preservation of biological evidence, such as evidence collection/storage devices and preservatives/additives intended for application to biological materials.

\section{Disclaimer}

The opinions, findings and conclusions or recommendations expressed in this publication/program/exhibition are those of the author(s) and do not necessarily reflect those of the Department of Justice.

\section{Author contributions}

The authors are listed in order of lead and second author, based on their contributions. Both authors contributed to the outline, first and subsequent drafts, and assessment and incorporation of the comments received during the review phase; reviewed each draft critically; approved the final draft; and met ICMJE criteria for authorship.

\section{Acknowledgments}

The authors thank Douglas Ryan for his work preparing and processing the many samples that were involved in this project.

\section{Financial \& competing interests disclosure}

This project was supported by award no. 2015-R2-CX-K037, awarded by the National Institute of Justice, Office of Justice Programs, US Department of Justice. The authors have no relevant affiliations or financial involvement with any organization or entity with a financial interest in or financial conflict with the subject matter or materials discussed in the manuscript.

No writing assistance was utilized in the production of this manuscript.

\section{Ethical conduct of research}

The authors state that they have obtained appropriate institutional review board approval for this work, and informed consent has been obtained from the participants involved.

\section{Open access}

This work is licensed under the Attribution-NonCommercial-NoDerivatives 4.0 Unported License. To view a copy of this license, visit http://creativecommons.org/licenses/by-nc-nd/4.0/

\section{References}

Papers of special note have been highlighted as: $\bullet$ of interest; $\bullet \bullet$ of considerable interest

1. Harty LC, Garcia-Closas M, Rothman N, Reid YA, Tucker MA, Hartge P. Collection of buccal cell DNA using treated cards. Cancer Epidemiol. Biomarkers Prev. 9(5), 501-506 (2000).

2. Kline MC, Duewer DL, Redman JW, Butler JM, Boyer DA. Polymerase chain reaction amplification of DNA from aged blood stains: quantitative evaluation of the 'suitability for purpose' of four filter papers as archival media. Anal. Chem. 74(8), 1863-1869 (2002).

3. Sigurdson AJ, Ha M, Cosentino M et al. Long-term storage and recovery of buccal cell DNA from treated cards. Cancer Epidemiol. Biomarkers Prev. 15(2), 385-388 (2006).

4. Mas S, Crescenti A, Gassó P, Vidal-Taboada JM, Lafuente A. DNA cards: determinants of DNA yield and quality in collecting genetic samples for pharmacogenetic studies. Basic Clin. Pharmacol. Toxicol. 101(2), 132-137 (2007).

5. Alaeddini R, Walsh SJ, Abbas A. Forensic implications of genetic analyses from degraded DNA - a review. Forensic Sci. Int. Genet. 4(3), 148-157 (2010).

6. Bonnet J, Colotte M, Coudy D et al. Chain and conformation stability of solid-state DNA: implications for room temperature storage. Nucleic Acids Res. 38(5), 1531-1546 (2010).

7. Strom KJ, Ropero-Miller J, Jones S, Sikes N, Pope M, Horstmann N. The 2007 Survey of Law Enforcement Forensic Evidence Processing. RTI International, Research Triangle Park, NC, USA (2009).

8. Hayes J. Forensic Testing Turnaround Time in 50 States. Office of Legislative Research, Hartford, CN, USA (2010).

9. Hemmerich KJ. General aging theory and simplified protocol for accelerated aging of medical devices. Med. Plast. Biomater. 5, 16-23 (1998).

- Discusses the simplified protocol for accelerated aging and its common use in simulating aging of medical devices.

10. Hukins DWL, Mahomed A, Kukureka SN. Accelerated aging for testing polymeric biomaterials and medical devices. Med. Eng. Phys. 30(10), 1270-1274 (2008).

-. Discusses the simplified protocol for accelerated aging and its common use in simulating aging of medical devices. 
11. Clermont D, Santoni S, Saker S, Gomard M, Gardais E, Bizet C. Assessment of DNA encapsulation, a new room temperature DNA storage method. Biopreserv. Biobank. 12(3), 176-183 (2014).

- Accelerated aging was used to simulate long-term storage of extracted DNA that contained additives to stabilize it for room temperature storage.

12. Lee SB, Clabaugh KC, Silva B et al. Assessing a novel room temperature DNA storage medium for forensic biological samples. Forensic Sci. Int. Genet. 6(1), 31-40 (2012).

- Another additive that enables room temperature DNA storage was also evaluated using accelerated aging to simulate long-term storage of extracted DNA.

13. Hedman J, Ansell R, Nordgaard A. Ranking index for quality assessment of forensic DNA profiles. BMC Res. Notes 3(1), 290 (2010).

- Presents the use and development of the forensic DNA profile index, a quality score developed to assess the quality of short tandem repeat profiles. 